\title{
Increased Benefits of Calamus manan Miq. Fruit by Its Potential Bioactivity
}

\author{
Heriad Daud Salusu ${ }^{1,2^{*}}$ Farida Ariani ${ }^{2}$ Edy Budiarso ${ }^{3}$ Irawan Wijaya Kusuma ${ }^{4}$ \\ Enos Tangke Arung ${ }^{4}$
}

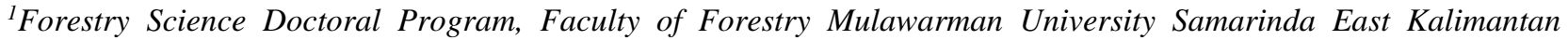 \\ Indonesia \\ ${ }^{2}$ Laboratory of Wood Properties and Product Analysis Samarinda State Polytechnic of Agriculture Indonesia \\ ${ }^{3}$ Laboratory of Wood Preservative Faculty of Forestry Mulawarman University Indonesia \\ ${ }^{4}$ Laboratory of Forest Product Chemistry Faculty of Forestry Mulawarman University Indonesia \\ *Corresponding author. Email: risaldaud@gmail.com
}

\begin{abstract}
Rattan manau (Calamus manan Miq.) is one of some commercial rattan species that grow in East Kalimantan forests. Its fruit is edible, similarly to some other species' fruits, and the local community traditionally uses it as medicine for stomach and toothache. There has not been any research related to investigating its fruit's benefits for medical purposes or others. This study aims to determine the potential of bioactivity in Calamus manan Miq's fruit, including some of its properties, such as phytochemical content, antioxidant, toxicity, and antibacterial activity. Parts of fruit, pericarp, flesh and seed were examined by using ethanol as a solvent. The study results show that the pericarp and seed have higher antioxidant activity than fruit flesh where the seed has an IC50 value of 25,04 ppm, the pericarp of $41,17 \mathrm{ppm}$ and fruit flesh of $170,19 \mathrm{ppm}$. The examination result of toxicity properties using the BSLT (Brine Shrimp Lethality Test) test shows the fruit of rattan manau is not toxic. Examination on antibacterial activity for two types of bacteria showed that pericarp and seeds have antibacterial activity against Escherichia coli, rated as an intense level. In contrast, for Streptococcus mutans it is rated as a weak category.
\end{abstract}

Keywords: Antioxidant, Toxicity, Antibacterial, Rattan, Calamus

\section{INTRODUCTION}

Rattan is one of the non-timber forest products that has been known for a long time. One of the rattan types with a high commercial value is manau rattan (Calamus manan Miq.). The economic value of rattan is the trunk and manau rattan stems, which are of high quality to be used as various types of handicraft products and furniture. In addition to the stems of other parts of rattan plants, beneficial to humans is the fruit. Manau rattan fruit is one of several edible fruit types. Even though the fruit is edible, its economic value is much lower than the stem. Rattan fruit is often traded by communities around the forest, especially by Dayak tribes in East Kalimantan. Traditionally, rattan fruit is considered to have properties for health, especially used as a reliever for abdominal pain and as a thrush medicine.
Manau rattan has not too large fruit, with a length of approximately $3 \mathrm{~cm}$, a diameter of about $2 \mathrm{~cm}$, scaly, and oval-shaped. The oval-shaped seeds measuring $18 \mathrm{x}$ $22 \mathrm{~mm}$ on the surface are speckled smooth and covered in light yellow flesh to slightly whitish. Manau rattan fruit has a sweet and sour taste. In the fruit season, it is often found sold in traditional markets [1].

One effort to increase the benefits of manau rattan fruit is to explore the bioactive potential contained in the fruit. This potential is developed into a product that is beneficial to human life. Bioactive components have physiological activities that can have a positive effect on body health.

Some rattan species have been investigated for their potential bioactivity, including Calamus erectus Roxb which has high antioxidant properties and has the potential as antidiabetic because it contains high phenol [2]. In other rattan types, the Calamus rotang L. has 
fruit antioxidant potential and is also useful as an antidiarrheal [3].

This study aims to determine the bioactivity potential of manau rattan in the skin, fruit flesh and seeds carried out through phytochemical, antioxidant, antibacterial and toxicity testing. To determine the potential of bioactive compounds in manau rattan fruit, the phytochemical, antioxidant, toxicity, and antibacterial content of the skin, fruit flesh, and seeds were tested using ethanol as a solvent.

\section{METHOD}

Manau rattan fruit is separated on the pericarp, flesh and seeds and then dried at room temperature before being processed to produce a powder. The fruit powder was extracted using the maceration method using ethanol as a solvent. The sample powder was immersed in ethanol for 48 hours, with a ratio of 1:10 (powder: solvent). The maceration results were evaporated using a rotary vacuum evaporator at a temperature of $30^{\circ}-40^{\circ} \mathrm{C}$ so that a crude extract was obtained.

\subsection{Phytochemical Test}

The tests were carried out qualitatively on the phytochemical components as follows:

\subsubsection{Alkaloids}

Identification is carried out using Dragendorff's solution. A total of $5 \mathrm{ml}$ of extract was added with $2 \mathrm{ml}$ of $\mathrm{HCl}$, then $1 \mathrm{ml}$ of Dragendorff's solution was added. The colour change of the solution to orange or red indicates that the extract contains alkaloids [4].

\subsubsection{Flavonoids}

A total of $1 \mathrm{ml}$ of sample extract was given a few drops of dilute sodium hydroxide $(\mathrm{NaOH} 1 \%)$. The appearance of a clear yellow colour in the extract solution and becomes colourless after the addition of dilute acid $(\mathrm{HCl} 1 \%)$ indicates the presence of flavonoids [4].

\subsubsection{Saponins}

The test is carried out by inserting as much as $10 \mathrm{ml}$ of hot water into a test tube containing $1 \mathrm{ml}$ of the test sample which has been dissolved in acetone. Then the solution is cooled and shaken for 10 seconds. The formation of solid foam for about 10 minutes with a height of 1-10 cm and not lost when added one drop of $\mathrm{HCl} 2 \mathrm{~N}$ indicates that the extract tested contains saponins [5].

\subsubsection{Tannins}

The test was carried out by inserting $10 \mathrm{ml}$ of the extract solution into a test tube and adding a lead acetate $(\mathrm{CH} 3 \mathrm{COO}) 2 \mathrm{~Pb} 1 \%$ solution. Tannins are positive if the yellow precipitate is formed [4]

\subsubsection{Triterpenoids and Steroids}

Identification was carried out using a mixture of acetic acid anhydride and concentrated sulfuric acid, commonly known as Liebermann-Burchard reagent. In this test, ten drops of acetic acid anhydride and two drops of concentrated sulfuric acid were added sequentially into $1 \mathrm{ml}$ of the test sample dissolved in acetone. Then the test sample was shaken and left for a few minutes. A change follows the colour reaction, if the colour is red and purple, the test is positive for triterpenoid, and if it looks green and blue, the test is positive for steroids [5]

\subsection{Antioxidant Test}

The antioxidant analysis used methods according to reference with modifications [6]. The absorbance of extract samples against free radicals was tested using $\mathrm{UV}-\mathrm{V}$ is Spectrophotometer at room temperature $\left(25^{\circ} \mathrm{C}\right)$ with a wavelength of $517 \mathrm{~nm}$ and DPPH (1,1-diphenyl2picrylhdrazyl), which functions like free radicals and ascorbic acid as a positive control. $33 \mu \mathrm{l}$ of extract sample dissolved in DMSO was put into a tube, added $467 \mu \mathrm{l}$ of ethanol, then homogenized between solvent and sample, then added $500 \mu \mathrm{l}$ of DPPH incubated for 20 minutes at room temperature without light. Tests were carried out with a concentration of $50 \mathrm{ppm}$ for initial screening, then a decrease in concentration was $3.125 \mathrm{ppm}, 6.25 \mathrm{ppm}, 12.5 \mathrm{ppm}$ and $25 \mathrm{ppm}$. Referring to the absorbance value in the sample extract, antioxidant activity was determined based on the relative inhibition percentage using the following equation: Relative Inhibition Activity (\%)

$(\%)=\frac{A_{0}-A_{1}}{A_{0}} \times 100 \%$

Note: A0 is the absorbance of DPPH,

A1 is the absorbance of the extracted sample.

Antioxidant activity was determined based on IC50 value (inhibitory concentration), namely the number of sample solutions needed to inhibit 50\% DPPH free radicals, which was calculated using a regression equation in which the extract concentration was on the $\mathrm{X}$-axis and the relative inhibition value on the $\mathrm{Y}$ axis, using the regression equation as following:

$\mathrm{Y}=\mathrm{b}+\mathrm{aX}$ 


\subsection{Antibacterial Test}

Antibacterials were tested using diffusion methods [7] with modifications. Tests were carried out on Eschericia coli and Streptococcus mutans bacteria. Chloramphenicol, which functions as an antibiotic against bacteria, was used as a positive control and acetone as a negative control. A total of $20 \mathrm{ml}$ of agar nutrient is placed in a petri dish that has been sterilized in an autoclave. Then, $100 \mu \mathrm{L}$ of bacteria is spread evenly to the petri dish. Furthermore, the well hole was filled with extract samples with a concentration of 25 $\mu \mathrm{g} / \mathrm{well}, 50 \mu \mathrm{g} / \mathrm{well}, 100 \mu \mathrm{g} / \mathrm{well}$ and $200 \mu \mathrm{g} /$ well and incubated for 24 hours at $37^{\circ} \mathrm{C}$. Observations were made by measuring the inhibition diameter that formed a clear zone around the well hole.

\subsection{Toxicity Test}

Testing of toxicity properties was carried out by the Brine Shrimp Lethality Test (BSLT) method using Artemia salina Leach microorganisms as test animals [8]. Tests at concentrations of 10, 100, 250 and 500 ppm each of 3 replications. Negative controls used seawater and potassium dichromate $\left(\mathrm{K}_{2} \mathrm{Cr}_{2} \mathrm{O}_{7}\right)$ as positive controls. One day artemia (nauplii) was included in the extract of each sample of 10 and placed in a sufficiently light place for 24 hours. The test is done by counting the number of living and dead artemia. Furthermore, the level of toxicity was analyzed using probit analysis to determine the $\mathrm{LC}_{50}$ value.

\section{RESULT AND DISCUSSION}

\subsection{Phytochemicals}

The phytochemical content of rattan manau can be seen in Table 1. Data shows that the pericarp contains flavonoids, alkaloids, tannins and teriterpenoids, fruit flesh contains flavonoids, saponins, tannins and triterpenoids, and seeds contain flavonoids, alkaloids, tannins and triterpenoids. The presence of phytochemical compounds in extracts of pericarp, flesh and seeds in manau rattan fruit has pharmacological effects such as antioxidants and antibacterials. Phytochemical potential can be used as an antibacterial, antioxidant and antimutagenic agent [9].

\subsection{Antioxidants}

Antioxidant chemical compounds are electron donor compounds. Biologically, notion of antioxidants is a compound that can counteract or reduce the adverse effects of oxidants. Antioxidants work by donating electrons to oxidant compounds so that the activity of oxidant compounds can be inhibited. Antioxidants' role is crucial in reducing the effects of free radicals, which are closely related to degenerative diseases such as coronary heart disease, high blood pressure, diabetes and cancer based on biochemical processes in the body. Free radicals are produced continuously during normal metabolic processes and are considered a cause of damage to body cells' function, which eventually triggers degenerative diseases [10].

DPPH test is an easy method for filtering some antioxidant molecules because the reaction can be observed visually and calculated in light intensity using simple spectrophotometry. In this method, DPPH acts as a free radical that will react with antioxidant compounds so that DPPH will change to 1,1-diphenyl-2picrylhydrazyl, which is not radical. An increase in the amount of 1,1-diphenyl-2-picrylhydrazyl will be marked by a dark purple change to pale yellow or pale and can be observed using a spectrophotometer so that free radical activity from the sample can be determined [11].

This method's parameter is $50 \%$ Inhibition Concentration (IC50), which is the concentration value that can inhibit $50 \%$ of free radical activity. The relationship between the concentration of pericarp, flesh and seed extracts and ascorbic acid as a positive control of DPPH inhibition is shown in Figure 1. The graph shows a linear relationship between extract concentration and DPPH relative inhibition.

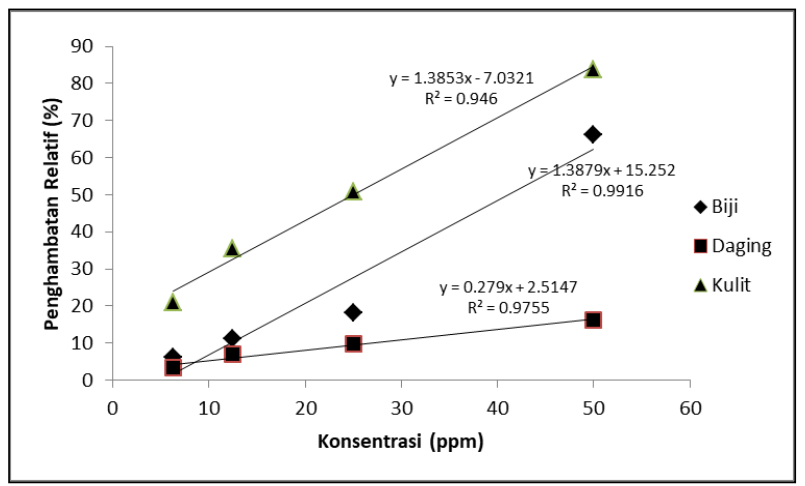

Figure 1 Antioxidant Activity in Manau Rattan Fruit (Calamus manan Miq).

The highest inhibition is found in the pericarp, followed by seeds and the lowest fruit flesh inhibition. Furthermore, determining the sample's effectiveness in inhibiting free radicals based on $\mathrm{IC}_{50}$ values can be seen in Table 2.

A low $\mathrm{IC}_{50}$ value indicates strong antioxidants. The classification of antioxidant activity is if the $\mathrm{IC}_{50}$ value is smaller than $50 \mu \mathrm{g} / \mathrm{ml}$ in the strong category; a value of $50 \mu \mathrm{g} / \mathrm{ml}$ to $100 \mu \mathrm{g} / \mathrm{ml}$ active category; a value of $100 \mu \mathrm{g} / \mathrm{ml}$ to $250 \mu \mathrm{g} / \mathrm{ml}$ moderate category; a value of $250 \mu \mathrm{g} / \mathrm{ml}$ to $500 \mu \mathrm{g} / \mathrm{ml}$ weak category; and more than $500 \mu \mathrm{g} / \mathrm{ml}$ inactive category [12]. 
Table 1. Phytochemical content of Calamus manan fruit.

\begin{tabular}{|c|c|c|c|}
\hline Phytochemical & Pericarp & Flesh & Seed \\
\hline Flavonoids & + & + & + \\
\hline Alkaloids & + & - & + \\
\hline Saponins & + & + & - \\
\hline Tannins & + & + & + \\
\hline Triterpenoids & + & + & + \\
\hline Steroids & - & - & - \\
\hline
\end{tabular}

Note: $+=$ detected, $-=$ not detected

Table 2. IC50 Values on Manau Rattan Fruit Extract (C. manan Miq.)

\begin{tabular}{|c|c|c|}
\hline Sample & $\mathrm{IC}_{50}(\mu \mathrm{g} / \mathrm{ml})$ & Note \\
\hline Pericarp & 41.17 & Strong \\
\hline Flesh & 170.19 & Moderate \\
\hline Seed & 25.04 & Strong \\
\hline
\end{tabular}

Table 2 shows that seeds and pericarp have solid antioxidant activity while fruit flesh is moderate. According to previous research on Calamus tenuis Roxb, it was shown that the high content of total phenols and flavonoids in fruit extracts correlated with antioxidant activity [13]. Antioxidant activity in all three parts of the fruit is affected by flavonoid content. In addition, alkaloids can also contribute to high antioxidant activity in the pericarp. Alkaloids and phenols are the essential substances that contribute to antioxidants in maca fruit (Lepidium meyenii). Alkaloids tend to have a stronger correlation to antioxidants than phenols [14]. Overall, the phytochemical content contributes to high antioxidant activity in the pericarp and seeds even though the pericarp is not an edible part but can be developed as a source of antioxidants.

\subsection{Antibacterial}

Antibacterials are substances that can inhibit growth and development or even kill microorganisms without damaging human life. Antibacterial activity was tested in two types of bacteria, namely Escherichia coli and Steptrococcus mutans. E. coli is a gram-negative bacterium that usually lives in humans and animals' intestines, which can cause mild diarrhoea or can cause intestinal severe infections such as diarrhoea, abdominal pain, and fever. $S$. mutans is a gram-positive bacterium, a bacterium found in the human oral cavity that significantly contributes to tooth decay.

The method used is agar diffusion and chloramphenicol; one of the antibiotics against bacteria is used as a positive control. The test results shown in Table 4 show different activities in each part of the fruit observed.
The test results showed different inhibition zones at each extract concentration. Pericarp and seed extracts showed higher inhibition of both types of bacteria compared to fruit flesh. In general, the data showed that the pericarp could inhibit two types of bacteria tested because they contained alkaloids. This is in line with previous research [15], which states that alkaloids can function as antimicrobials because they can interfere with bacterial cell division. The alkaloid content has antibacterial ability because it has a quaternary aromatic group that can interact with DNA [16]. Besides that, alkaloids can also interfere with the integrity of the peptidoglycan component in bacterial cells. Peptidoglycan is a component of the building of bacterial cell walls so that interference will cause the cell wall layer not to form intact and cause cell death [17].

Tannins, including phytochemical compounds, were detected in all three test samples, where tannins also have antibacterial potential. The antibacterial mechanism possessed by tannins is its ability to inhibit the synthesis of chitin used to form cell walls in fungi and damage the cell membrane so that fungal growth is inhibited. Tannins are also lipophilic compounds that are easily attached to the cell wall and cause damage to the cell wall [17].

Triterpenoids detected in all test samples also have antibacterial properties. The triterpenoid mechanism as an antibacterial reacts with porin (transmembrane protein), found on the bacterial cell wall's outer membrane to form a strong polymer bond that causes damage to the porin. Porin damage will reduce bacterial cell walls' permeability and cause bacterial cells to lack nutrients so that bacterial growth is inhibited or dead [18]. 
Table 4. Antibacterial Activity in Manau Rattan Fruit (C. manan Miq.)

\begin{tabular}{|c|c|c|c|c|}
\hline \multirow{2}{*}{ Type of bacteria } & \multirow{2}{*}{ Concentration ( $\mu \mathrm{g} /$ well) } & \multicolumn{3}{|c|}{ The diameter of the Inhibitory Zone ( $\mathrm{mm})$} \\
\hline & & Pericarp & Flesh & Seed \\
\hline \multirow[t]{4}{*}{ Escherichia coli } & 25 & 7.44 & 0.00 & 6.67 \\
\hline & 50 & 8.44 & 0.00 & 6.67 \\
\hline & 100 & 9.11 & 0.00 & 8.40 \\
\hline & 200 & 10.56 & 10.33 & 9.40 \\
\hline \multirow[t]{4}{*}{ Steptrococcus mutans } & 25 & 0.00 & 0.00 & 7.00 \\
\hline & 50 & 7.78 & 7.10 & 7.30 \\
\hline & 100 & 8.11 & 7.78 & 8.00 \\
\hline & 200 & 10.00 & 7.89 & 9.67 \\
\hline Chloramphenicol & 10 & 40.33 & 41.22 & 40.22 \\
\hline
\end{tabular}

Table 5. Mortality Rate of Artemia salina Leach Shrimp Larvae in Extracting Manau Rattan Fruit Sample at 10,000 ppm Concentration

\begin{tabular}{|c|c|c|c|c|c|c|}
\hline \multirow{2}{*}{ Samples } & \multirow{2}{*}{ Shrimp Amount } & \multicolumn{3}{|c|}{ Mortality in Replication } & \multirow{2}{*}{ Mortality (\%) } & \multirow{2}{*}{ Notes } \\
\hline & & 1 & 2 & 3 & & \\
\hline Seed & 10 & 1 & 2 & 1 & $13 \%$ & Non Toxic \\
\hline Pericarp & 10 & 2 & 0 & 2 & $13 \%$ & Non Toxic \\
\hline Flesh & 10 & 2 & 3 & 2 & $23 \%$ & Non Toxic \\
\hline
\end{tabular}

\subsection{Toxicity}

Toxicity testing used the Brine Shrimp Lethality Test (BSLT) method [8], using an animal test for saltwater shrimps (Artemia salina Leach). Testing using test animals is the initial stage of a series of toxicity tests of active compounds in plants before using them. The test begins at a concentration of $10,000 \mathrm{ppm}$ to determine the toxic level of the sample. If the number of shrimp that died $50 \%$ or more in each extracted sample, then the test continued at a lower concentration to determine the level of toxicity (LC50). The extract concentration of the sample used was $10100 \mathrm{ppm}, 250$ $\mathrm{ppm}$ and $500 \mathrm{ppm}$. The results of testing at a concentration of $10,000 \mathrm{ppm}$ can be seen in Table 5 below.

Based on the data in Table 5 shows that the average mortality of artemia shrimp larvae is below $50 \%$, so that the test is not continued to determine the LC50 value so that it can be concluded that the fruit of Calamus manau in the three parts of the fruit tested is not toxic.

\section{CONCLUSION}

The results revealed that the manau rattan fruit (Calamus manan Miq) had bioactivity potential in each part of the fruit, where the highest antioxidant activity was found in the pericarp and seeds, which were included in the strong category and fruit flesh was in the moderate category, antibacterial activity against $E$. coli bacteria and $S$. mutans is stronger in the pericarp, and the three parts of the fruit are not toxic. Overall the flesh and seeds have better bioactivity than fruit flesh.

\section{ACKNOWLEDGMENTS}

The Directorate of Research and Development funded this research, Ministry of Research, Technology and Higher Education, Republic of Indonesia, through the 2017 Doctoral Dissertation Grant program. The author expressed his gratitude for the funding support of this research to be adequately resolved.

\section{REFERENCES}

[1] J. Dransfield, N. Manokaran, Sumber Daya Nabati Asia Tenggara 6: Rotan, Gadjah Mada University Press dan Prosea Indonesia, 1996.

[2] M. Ghosal, P. Mandal, In-Vitro Antidiabetic and Antioxidant Activity of Calamus erectus Roxb. Fruit: A Wild Plant of Darjeeling Himalaya, International Journal of Pharma and BioSciences, 4(2), 2013, pp. 671-684. 
[3] A. Shil, M.K. Himel, A. Khair, M.N. Alam, J. Uddin, In vitro Antioxidant Activity of the Methanolic Extracts of Leaf and Fruit of Calamus rotang Linn, J. Expt. Biosci., 3(2), 2012, pp. 3336.

[4] C.K. Kokate, Pharmacognosy, 16th Edn, Nirali Prakashan, Mumbai, India, 2001.

[5] J.B. Harborne, Phytochemical Methods, ITB Press, Bandung, 1987.

[6] E.T. Arung, I.W. Kusuma, E.O. Christy, K.S. Kondo, Evaluation of medicinal plants from Central Kalimantan for antimelanogenesis, J. Nat. Med., 63(4), 2009, pp. 473-480.

[7] J.G. Cappucino, N. Sherman, Microbiology: A Laboratory Manual, 2nd Edition, The Benjamin Cummings Publishing Company, Rockland Community College, State University of New York, 2001.

[8] B.N.F. Meyer, J.E. Putnam, L.B Jacobsen, D.E. Nicholas, J.L. McLaughin, Brine Shrimp: A Convenient General Bioassay for Active Plant Constituents, Planta Medica, 45, 1982, pp. 4-31.

[9] G. Zengin, A. Uysal, E. Gunes, A. Aktumsek, Survey of Phytochemical Composition and Biological Effects of Three Extracts from a Wild Plant (Cotoneaster nummularia Fisch. et Mey.): A Potential Source for Functional Food Ingredients and Drug Formulations, PLOS ONE, 9(11), 2014, e113527.

[10] M.F. Abu Bakar, E.A. Nor, A.K. Fifilyana, S. Syazlina, Phytochemicals and Antioxidative Properties of Borneo Indigenous Liposu (Baccaurea lanceolata) and Tampoi (Baccaurea macrocarpa) Fruits, Antioxidants, 3, 2014, pp. 516-525. DOI:10.3390/antiox3030516

[11] S.B. Shetty, P. Mahin-Syed-Ismail, S. Varghese, B. Thomas-George, P.K. Thajuraj, D. Baby, S. Haleem, S. Sreedhar, D. Devang-Divakar, Antimicrobial effects of Citrus sinensis peel extracts against dental caries bacteria: An in vitro study, J Clin Exp Dent, 8(1), 2016, e70-7. doi: $10.4317 /$ jced.52493

[12] M.H.Y. Jun, J. Fong, X. Wan, C.S. Yang, C.T. Ho, Comparison of Antioxidant Activities of Isoflavones Form Kudzu Root (Puerarua labata O), Journal Food Science Institute of Technologist, 68, 2003, pp. 2117-2122.

[13] Z.U. Ahmed, S.B. Seheli, R.K. Minhozur, H. Mofazzol, S. Shriya, R.R. Satyajit, Phytochemical Screening, Antioxidant and Cytotoxic Activity of
Fruit Extract of Calamus tenuis Roxb., Journal of Coastal Life Medicine, 2(8), 2014, pp. 645-650.

[14] J. Gan, Y. Feng, Z. He, X. Li, H. Zhang, Correlations between Antioxidant Activity and Alkaloids and Phenols of Maca (Lepidium meyenii), Journal of Food Quality, 2017, pp. 1-10. https://doi.org/10.1155/2017/3185945

[15] D.E. Djeussi, J.A.K. Noumedem, J.A. Seukep, A.G. Fankam, I.K. Voukeng, B. Simplice, S.B. Tankeo, A. Nkuete, V. Kuete, Antibacterial Activities of Selected Edible Plants Extracts Against Multidrug-resistant Gram-negative Bacteria, BMC Complementary and Alternative Medicine, 13, 2013, p. 164.

[16] R.M. Hassan, R.H. Raheema, Evaluation The Antibacterial Effect of Alkaloids and Phenols Extraction from Hibiscus sabdariffa Against Uti Infection In Vitro, European Journal of Pharmaceutical and Medical Research, 3(3), 2016, pp. 22-25.

[17] F.A. Rahman, T. Haniastuti, T.W. Utami, Phytochemical Screening and Antibacterial Activity of Ethanol Extract of Soursop Leaf (Annona muricata L.) on Streptococcus mutans ATCC 35668, Indonesian Dentistry Magazine, 3(1), 2017, pp. 1-7.

[18] J.L. Guil-Guerrero, L. Ramos, C. Moreno, J.C. Zúñiga-Paredes, M. Carlosama-Yepez, P. Ruales, Antimicrobial activity of plant-food by-products: A review focusing on the tropics, Livestock Science, 189, 2016, pp. 32-49. DOI:10.1016/j.livsci.2016.04.021 